\title{
A Gender-based Study of Iranian EFL Learners' Pragmatic Awareness: The Role of Receptive Skill-based Teaching
}

\author{
Ali Zangoei \\ University of Sistan and Baluchestan \\ Department of English Language and Literature, Zahedan, Iran \\ E-mail: Zangoei.ali@gmail.com \\ Esmaeel Nourmohammadi \\ University of Sistan and Baluchestan \\ Department of English Language and Literature, Zahedan, Iran \\ E-mail: Esmaeel.nm@gmail.com \\ Ali Derakhshan \\ English Language and Literature Department, Golestan University, Iran \\ E-mail: aderakhshanh@gmail.com
}

Received: 06-05-2014

doi:10.7575/aiac.ijalel.v.3n.6p.53
Accepted: 25-06-2014

Published: 01-11-2014

\begin{abstract}
This study explored the effects of contextual factors, namely exposure to instruction and gender difference on Iranian EFL learners' pragmatic perception of the illocutionary act of apology. To this end, sixty four upper-intermediate English learners (34 males \& 30 females ranging in age from 17 to 27), from a language institute in a city in northeastern Iran, voluntarily took part in the study. While investigation of the effect of explicit instruction of apology speech act, through consciousness-raising listening prompts, on EFL learners' interlanguage pragmatic competence is one of the current study's prime concerns, the participants, who were equally assigned to an experimental group and a control group, were given 14 sessions of instruction accompanied, merely within the experimental class, by consciousnessraising activities via listening prompts. Adopting a multiple choice discourse completion task (MDCT) as both the pretest and post-test, the results confirmed the beneficial effect of listening-based teaching of apology speech act juxtaposed with consciousness-raising activities on the learners' pragmatic awareness. Besides, the context-external factor of gender yielded a significant impact on the way females and males, in the experimental group, perceived the communicative act of apology. In the light of the findings, the study provides implications for curriculum designers, materials developers, and language teachers.
\end{abstract}

Keywords: Awareness-raising; interlanguage pragmatics; listening prompts; pragmatic competence; speech act

\section{Introduction}

Interlanguage pragmatics (ILP) which studies nonnative speakers' acquisition and production of linguistic action patterns or speech acts in a second language (L2)has aroused research interest in recent years(Kasper \& Blum-Kulka, 1993); however, most ILP studies have been production-oriented (Alcon, 2005; Takahashi2001; Takemoto, 2012), focusing mainly on learners' speech act strategies in their 'linguistic' output. Thus, the study of speakers' perception of speech acts, namely apology has received insufficient attention, for the literature entails few scholarly attempts concerning perception-oriented study of English speech acts, particularly of the universal speech act of apology (Bergman \& Kasper 1993).

Speaking a language entails more than uttering a number of grammatically correct sentences. A number of comprehensive models of communicative competence (e.g., Bachman \& Palmer 1996;Canale\& Swain 1980) recognize that becoming a competent second language user encompasses knowing more than just the correct rules and forms of a language; it also involves knowing how to use language in social and pragmatic appropriate ways. Tanck (2002) states that "Speakers who may be considered "fluent" in a second language due to their mastery of the grammar and vocabulary of that language may still lack pragmatic competence; in other words, they may still be unable to produce and comprehend language that is socially and culturally appropriate" (p.1). Communicative or pragmatic competence is the ability to use language forms in a wide range of environments, factoring in the relationships between the speakers involved and the social and cultural context of the situation (Gass \& Selinker, 2008; Lightbown \& Spada, 1999).

Many studies have recognized that a learner's ability to use speech acts appropriately is a major part of pragmatic competence. Rintell (1979) defines pragmatics as the study of speech acts and argues that the learner's pragmatic ability in the target language is reflected in how one produces utterances to communicate 'specific intentions' and how one interprets other speakers' intentions as conveyed by these utterances. Communicative acts or simply speech acts have 
proved to be one of the attractive areas in pragmatics and sociolinguistics. One of the most important speech acts is apology. It has long attracted the attention of scholars dealing with social and cultural patterns in language. Apologies have been mostly investigated in the field of cross-cultural pragmatics to compare the use of apology speech act between native English speakers and native speakers of other languages like Spanish (Garcia, 1989), German (House, 1988), Austrian (Meier 1996), and Persian (Eslami-Rasekh, 2004). More recently, however, research findings indicate that there are considerable differences between L2 learners and native speakers with regard to their perception and production of speech acts (Bardovi-Harlig,2001).

Pragmatic ability is an essential component of communicative competence the absence of which could cause communicative problems (Salazar, 2008). As Eslami-Rasekh, Eslami-Rasekh, and Fatahi (2004) pinpoint "It is necessary to understand and create language that is appropriate to the situations in which one is functioning, because failure to do so may cause users to miss key points that are being communicated or to have their messages misunderstood" (p. 1). Worse yet is the possibility of a total communication breakdown and the stereotypical labeling of second language users as people who are insensitive, rude, or inept (Thomas 1983). Breakdowns in communication usually occur as a result of the discrepancies that exist between different perceptions of utterances in two special cultures (Thomas 1983). These all signify the necessity of teaching the rules of appropriate language use because every language contains formulae which are basically governed by social and pragmatic aspect of contexts. Using these formulae in a proper context demands familiarity with and awareness of both linguistic knowledge and the social rules that encompass it (Afghari \& Karimnia, 2007).

Many studies have proved that pragmatic ability is teachable (e.g., Alcón, 2005; Alcón \& Pitarch; Rose, 2009). Many recent studies have adopted Schmidt's (1993) noticing hypothesis as their theoretical framework, for instance, Takahashi (2001), Yoshimi (2001), and Alcón (2005). These studies are good examples of teaching pragmatic competence. Judd (1999, p. 159) indicates that techniques for developing L2 pragmatic competence can be divided into three categories:

1. cognitive-awareness raising activities, such as presentation, discussion, and pragmatic-consciousness-raising techniques;

2. receptive-skills development by using teacher generated materials or natural data;

3. productive-skills teaching through role playing.

As an important part of pragmatic competence, speech act of apology has aroused a great research interest in the field of interlanguage pragmatics; however, previous studies (e.g., Blum-Kulka \& Olshtain, 1984) were cross-cultural and production-based in orientation. In response to the paucity of research on the perception of the speech act of apology, based on the second category of the above-mentioned techniques, the present study attempts to examine the effectiveness of listening prompts, as natural data and integrating them to consciousness-raising activities, on EFL Iranian learners' pragmatic awareness of the speech act of apology. Another dimension of the study is to see whether there is any significant difference in perception of the speech act of apology between males and females who have experienced the treatment. Consciousness-raising techniques in teaching this kind of pragmatic aspect are expected to be effective in promoting EFL learners' pragmatic competence and their ability to understand the pragmatic contrasts between their native and target language.

\section{Review of the Related Literature}

\subsection{Interlanguage Pragmatics (ILP): The Role Of instruction}

As a domain within second language studies, pragmatics is usually referred to as interlanguage pragmatics (ILP) drawing on an analogy with interlanguage grammar, interlanguage phonology, and interlanguage lexicon (Kasper \& Blum-Kulka, 1993; Kasper \& Rose, 2002). Interlanguage has been defined as a discipline concerning "the study of nonnative speakers' comprehension, production, and acquisition of linguistic action in L2" (Kasper, 1998, p. 184), or, as Kasper summarizes, interlanguage pragmatics investigates how to do things with words in a second language. ILP is the intersection of pragmatics which consists of features from a learner's First Language (L1) and Second Language (L2), in addition to some features which do not belong to either of these language systems. As defined by Kasper (1992),"ILP represents the branch of second language research which studies how non-native speakers (NNSs) understand and carry out linguistic actions in a target language and how they acquire L2 pragmatic knowledge" (p. 203). ILP encompasses a developing literature which addresses the acquisition of pragmatic competence in a second/foreign language (Rose, 2009).

Pragmatic competence, which is the ability to convey and interpret meaning appropriately in a social situation, has become an object of inquiry in a wide range of disciplines including linguistics, applied linguistics, anthropology, sociology, psychology, communication research, and cross cultural studies (Taguchi, 2009). Teaching pragmatics and its components and also factors which result in pragmatic learning development have been emphasized in pedagogical settings. Among these factors is the impact of instruction on learners' comprehension and production of speech acts which has induced scholars in the realm of interlanguage pragmatics to pay particular attention to this issue, especially in recent years (Alcón \& Pitarch, 2010). Indeed, the rationale for the need of instruction in pragmatics is provided by Schmidt's (1993) hypothesis that mere exposure to the target language does not guarantee a boost in pragmatic competence. His surmise was that pragmatic functions and relevant contextual features are often not noticed by L2 learners and hence less probably to be attended to even after prolonged exposure. Moreover, research addressing realization strategies of speech acts used by foreign language (FL) learners (Bardovi-Harlig, 2001; Bardovi-Harlig \& 
Hartford, 1993; Blum-Kulka \& Olshtain, 1984; Kasper, 1997; Kasper \& Rose, 2002) has highlighted the necessity of instruction in pragmatics based on the evidence that a high grammatical competence is not always indicative of a successful pragmatic performance in the TL.

It can be concluded, hence, that the significant role of L2 pragmatic instruction has been emphasized in the literature, particularly the study ofL2 speech acts as well as their perception and production within instructional environments has been widely accentuated in the field of interlanguage pragmatics (Taguchi, 2010). Qorina (2012) asserted that "speech acts reflect the essential cultural and social norms of the target language" (p. 7). According to Littlewood (1981), lacking the knowledge of cultural, social, and pragmatic aspects of languages in every communication can lead to misunderstanding and miscommunication, both in producing the appropriate speech act and perceiving the intended meaning of utterances. That is why we have to know how the perception of speech acts such as apology can be affected by some instructions in foreign language contexts

\subsection{The Speech Act of Apology}

One of the most influential notions in the study of language use is speech acts (Blum-Kulka et al, 1989). Searle (1969) asserted that "the speech act is the basic unit of communication" (p.39). He argued that speech acts are rule-governed forms of behavior, and that speech act rules are a part of linguistic competence. His principle of expressibility states that it is theoretically possible for any speaker to say exactly what he or she intends in any language, by increasingly understanding the rules for speaking the native language. Searle (1969) reasoned that all languages "can be regarded as different conventional realizations of the same underlying rules" (p. 39).Also, Hymes (1972) defines speech act as "the minimal unit of speech that has rules in terms both of where and when they may occur and of what their specific features are culturally named acts, such as complaining, apologizing, advising, and so on" (p. 269).

Speech acts have been studied from diverse perspectives, including linguistics, philosophy, and cultural anthropology. From a historical perspective, the study of speech acts originates in the philosophy of language (Blum-Kulka et al., 1989). The basic insights offered by the work of philosophers (Austin, 1962; Grice, 1975; Searle, 1969) are based on the assumptions that the minimal units of human communication are not linguistic expressions, but rather the performance of certain kinds of acts, such as greeting, apologizing, asking questions, and requesting help. Over the past two decades, speech act theory has been used as a theoretical basis for many cross-cultural and interlanguage pragmatic studies. Achiba (2003, p. 2) pointed out the importance of speech act theory for the studies of pragmatics:

According to speech act theory, speakers perform illocutionary acts by producing utterances. An illocutionary act is a particular language function performed by an utterance. That is, through their utterances speakers convey communicative intentions, such as requests, apologies, promises, advice, compliments, offers, refusals, compliments and thanking. The study of speech acts provides a useful means of relating linguistic form and communicative intent.

Speech acts have been claimed by some to operate by universal pragmatic principles (Austin, 1962; Searle, 1969). Others have shown them to vary in conceptualization and verbalization across cultures and languages (Wierzbicka, 1985; Wong, 1994). Although this debate has generated over three decades of research, only the last 15 years marked a shift from an intuitively based approach to an empirically based one, which "has focused on the perception and production of speech acts by learners of a second or foreign language at varying stages of language proficiency and in different social interactions" (Cohen, 1996, p. 385). Blum Kulka et al. (1989) argue that there is a strong need to complement theoretical studies of speech acts with empirical studies, based on speech acts produced by native speakers of individual languages in strictly defined contexts.

Apology was chosen as the focal speech act for this study as it is considered to be face-threatening speech act which has significant implications for miscommunication across cultures. Tuncel (2011) maintained that apologizing is considered to be one of the highly complex speech acts as it differs cross-culturally and very often prone to misunderstandings. According to Eslami-Rasekh and Mardani (2010), at the heart of cross cultural differences apology speech act varies across various socio-cultural systems. It is one of the problematic aspects of language learning for most foreign language learners. Apologies are of special importance since they imply the speaker's guilt and thus are facethreatening (Lakoff, 2001; Olshtain\& Cohen, 1989; Stenstrom, 1994).

\subsection{Previous Studies on the Speech Act of Apology}

Many studies have been carried out to investigate apology realization and speaker perception using different approaches. Interlanguage apology studies have generally investigated the production and perception of apologies by non-native language learners in ESL/EFL contexts. These studies were based on CCSARP project and aimed at establishing native speakers' patterns of realization, comparing speech acts across languages and establishing the similarities and differences between NSs and non-native speakers NNSs in the realization of these acts (Blum-Kulka \& Olshtain, 1984). They have compared the use of apologies in English with other languages such as German (Meier 1997), Russian (Olshtain\& Cohen, 1983), and Hebrew (Olshtain\& Cohen, 1983).According to Afghari and Karimnia(2012), the results in these studies have showed that participants from different groups used similar strategies and that there were cultural preferences in their use. The essential components of an apology for the majority of NNSs and NSs were explicit apology expressions and accounts.

Zimin (1981) investigated gender differences in apologies produced in two role-play situations. One involved an apology for refusing an invitation and the other an apology for being late. Twenty NNSs and 10 NSs of American English produced apology responses. Five male and five female graduate students served as raters, judging the deference of the responses using a five-point scale. An analysis of the effect of the addressee's gender on the use of 
deference revealed that generally women addressees elicited more deference than men; however, in certain situations where the apology for refusal was made, men received more deference than woman. Regarding the effect of the speaker's gender on the use of deference, there were no differences between males and females.

With an ethnographic method, Holmes (1989) studied apology strategies for speakers of New Zealand English. Among the various social factors, she found that gender greatly influenced the use of apology strategies. In general, women used more apologies than men did, women apologized to other women more than they did to men, and men used more apologies to women rather than to men.

Considering gender as the only variable, Tehrani, Rezaei, Dezhara, \&Kafrani(2012) researched the different sequential strategies used by Iranian EFL students in various situations and the effect of gender on using these strategies. The results showed that the statement of remorse was the strategy most frequently used by the male and female respondents across the sample, and the female participants used this strategy more frequently than the male participants.

\subsection{Enhancingl2 Pragmatic competence: The Effectiveness of Receptive Skill-Based Instruction and Consciousness- Raising}

One of the important principles of communicative language teaching is that authentic language should be used in instruction whenever possible (OmaggioHadley, 1993). Nunan (1999) defines authentic materials as spoken or written language data that has been produced in the course of genuine communication, and not specifically written for purposes of language teaching. Kasper (1997, p. 22) asserted that "Authentic L2 input is essential for pragmatic learning, but it does not secure successful pragmatic development". When students observe L2 communicative practices, their minds don't simply record what they hear and see like a video camera does. While there are various types of authentic materials, scholars such as Celce-Murcia (2001) insist on the use of authentic audio-taped materials as the basis for classroom learning activities. In the same vein, the present study adopted authentic listening materials accompanied by consciousness-raising tasks as an input enhancement method to explore their effectiveness on EFL learners' pragmatic competence.

According to Schmidt (1990), noticing or consciousness is a prerequisite for the acquisition of L2 pragmatic features. Pragmatic awareness-raising has been accentuated by other scholars, as well (Judd, 1999; Kasper \& Schmidt, 1996). Drawing on Schmidt's noticing hypothesis, Ellis (2003) assumed noticing as a way through which input is integrated into the learner's developing system. He also makes use of this concept (noticing) to distinguish between implicit knowledge "that knowledge of language that a speaker manifests in performance but has no awareness of" and explicit knowledge "knowledge about language that speakers are aware of and, if asked, can verbalize" (p. 105). The main distinction between the two approaches is that in explicit approach the learners are taught explicit meta-pragmatic information about the target language forms (Rose, 2009), but implicit approach involves providing feedback on language use while the primary attention is on meaning (Ellis, 2003).The distinction between explicit and implicit teaching has also been addressed by Doughty (2003). According to her, explicit teaching involves directing learners' attention towards the target forms with the aim of discussing those forms. In contrast, an implicit pedagogical approach aims to attract the learner's attention while avoiding any type of metalinguistic explanation and minimizing the interruption of the communicative situation.

In order to explore the effectiveness of both explicit and implicit treatments on learners' pragmatic awareness of suggestions, Martínez-Flor and Alcón Soler (2007) conducted a study. The EFL learners were divided into three intact classes: group $A(n=24)$ worked on awareness-raising and production tasks receiving explicit metapragmatic explanations on suggestions; group B $(n=25)$ was taught the use of suggestions by means of input enhancement and recast techniques; and group $\mathrm{C}(\mathrm{n}=32)$ was a control group that did not receive any instruction on suggestions. Results showed the positive effects of instruction on learners' pragmatic awareness of suggestions. In addition, findings illustrated the benefits of both explicit and more implicit instructional approaches to developing learners' pragmatic awareness in the EFL classroom.

Barekat (2013) focused on teaching English requestive downgrades forms through consciousness-raising instruction (C$\mathrm{R})$ and consciousness-raising instruction with feedback (C-R F). The results of pre-test, post-test, and follow-up test revealed that two treatment groups outperformed control group and C-R F group had a better performance than C-R group. And in another Iranian EFL setting, the impact of different types of pragmatic instruction on the production of apologetic utterances was studied by Kargar, Sedighi, and Ahmadi (2012)who found that the participants receiving explicit pragmatic instruction outperformed the implicit and control groups.

Birjandi and Derakhshan (2014) investigated the relative effectiveness of consciousness-raising video-driven prompts on the comprehension of three speech acts of apology, request, and refusal on seventy eight (36 male and 42 female) upper-intermediate Persian learners of English who were randomly assigned to four groups (metapragmatic, formsearch, role play, and control). The four groups were exposed to 45 video vignettes (15 for each speech act) extracted from different episodes of Flash Forward, Stargate TV Series and Annie Hall Film for nine 60-minute sessions of instruction twice a week. Results of the multiple choice discourse completion test (MDCT) indicated that learners' awareness of apologies, requests and refusals benefit from all three types of instruction, but the results of the Post hoc test of Tukey (HSD) illustrated that the metapragmatic group outperformed the other treatment groups, and form-search group had a better performance than role-play and control groups.

Despite ample research on the effect of diverse instructional approaches and input enhancement methods on EFL pragmatic development, there is a dearth of studies on the relationship between individual characteristics such as gender 
and interlanguage pragmatic development. Farashaiyan and Tan (2012) as a secondary purpose in their study investigated the relationship between gender and language proficiency and pragmatic knowledge. That is, the study examined whether there is any considerable variation in the performance of males and females regarding their pragmatic knowledge and language proficiency. A pragmatic competence test was used to determine the participants' pragmatic knowledge. It was revealed that the female participants performed better in pragmatic and proficiency tests than the male ones.

In another study, Safa and Mahmoodi (2012) attempted to see if any relationship could be found between EFL learners' lexico-grammatical and interlanguage pragmatic competences and if such a relationship could be found, whether the gender variable affected it or not. A group of one hundred ten male/female senior university EFL students took a standardized lexico-grammatical proficiency test and a researcher made and validated MDCT including four speech acts of disagreement, scolding, request and complaint at four levels of formality and familiarity. On the basis of the findings, a positive correlation between the learners' lexico-grammatical and pragmatic competences was disclosed. Furthermore, this positive correlation was more tangible among the female EFL learners than the male counterparts.

Regarding the scarcity of empirical work in the realm of ILP competence with a particular focus on the role of contextual variables in pragmatic awareness of L2 learners, the present study aims to make further contributions to the field by delving into the relative effectiveness of explicit instruction, through the receptive skill of listening, on Iranian EFL learners' comprehension of the speech act of apology.

\section{The Present Study}

The aim of the present study is twofold: it aims to show the possible effects of teaching pragmatics in an EFL context with the assumption that pragmatic failures can be overcome by giving the students opportunity to become aware of sociolinguistic and pragmalinguistic aspects of language. Moreover, the impact of gender, as a contextual factor, on learners' pragmatic perception is the other concern which the current study seeks to explore.

Taking the significant importance of ILP in learning and teaching an FL into account, the researcher has attempted to investigate innovative instructions by working on listening prompts in teaching pragmatic aspects of language such as speech act of apology which might lead to the improvement of Iranian learners' pragmatic comprehension ability.

This study is potentially significant because it investigates an area of ILP that has not been sufficiently explored. Moreover, it has a novel insight into the EFL classroom and the fact that there is no single approach to the teaching of pragmatics. The variety of approaches means that pragmatics can be integrated easily into any classroom whether traditional or communicative. There are a number of useful activities for pragmatic development. Consciousness raising activities are activities designed to develop recognition of how language forms are used appropriately in context (Eslami-Rasekh, 2004).

Based on the foregoing discussion, the following three research questions guided the present study:

1. Does explicit instruction of the speech act of apology through the receptive skill of listening affect Iranian EFL learners' pragmatic competence?

2. With respect to listening-based instruction of apology speech act, how do awareness-raising activities influence Iranian EFL learners' ILP perception?

3. Does the contextual factor of gender affect Iranian EFL learners' pragmatic comprehension with regard to receptive skill-based teaching of the illocutionary act of apology?

\subsection{Methodology}

\subsubsection{Participants}

The participants were comprised of 64 upper-intermediate English learners (34 males \& 30 females) selected randomly from a language institute ina city in north-eastern Iran. The learners, whose ages ranged from 17 to 27 , were assigned into two groups, each comprising of 15 female and 17 male participants

\subsubsection{Instrumentations}

The instruments employed in this study were as follows: (a) Nelson English Language Proficiency Test (Proficiency Test); and (b) Multiple choice pragmatic discourse completion task.

\subsubsection{Nelson English Language Proficiency Test}

In order to feel certain that all the learners were at the same level of language proficiency, "Nelson English Language Proficiency Test", developed by Fowler and Coe (1976), was administered at the very beginning. Although the Nelson test is a standard measurement, the researcher administered the test to a pilot group of 35 upper-intermediate EFL learners in the same institute in order to obtain the reliability of the test within the particular context of this study. According to KR-21 formula, the reliability index for the "Nelson English Language Proficiency Test" in the present study was found to be 0.85 , which is considered an acceptable level of reliability.

\subsubsection{Multiple Choice Pragmatic Discourse Completion Task Test}

Data, in this study, were gathered by a multiple choice pragmatic discourse completion task test (MDCT) for the speech act of apology. MDCT is a pragmatics instrument that requires students to read a written description of a situation, but, unlike the written discourse completion test (WDCT), an MDCT requires the students to select what would be best to say in that situation. 
The MDCT selected for this study was a standard multiple-choice format of one answer and two distracters. Being comprised of 21 situations associated with apology speech act, the test demanded that the students assess each situation and choose the most suitable answer out of the three possible choices. Although the MDCT was a combination of two reliable tests, the researcher estimated its post-test reliability to make certain the internal consistency of the prepared MDCT within the context of the current study. The reliability index was found to be 0.76 , which is, according to DeVellis (1991), a respectable reliability.

\subsection{Materials}

The study included a set of programmed instructional materials explaining the realization and interpretation patterns, rules, strategies, and tokens of the speech act of apology under the study. They were specifically developed based on intensive review of the related literature and aims of the study.

\subsubsection{Listening Prompts}

The study utilized authentic materials, namely listening prompts (LPs) which consisted of 20 tape-recorded conversations extracted from Interchange Series (Richards 2005), Tactics for Listening Series (Richards 2003), American Headway (Soars, Soars, Falla, \& Cassette 2002), and Top Notch (Saslow\& Ascher2006).To practice and perform apology speech act in a variety of situations, these LPs were accompanied by a number of follow-up activities, which then became input for subsequent in-class activities, such as oral reports or discussions.

\subsubsection{The Structured Form for Listening Prompts}

A modified version of Kasper's (1997) structured form, taken from Eslami-Rasekh (2005)was developed and assigned to the experimental group to engage learners in consciousness-raising $(\mathrm{C}-\mathrm{R})$ activities by asking them to determine the categories in each LPs and mark the characteristics of each apology speech act situation.

\subsection{Data Collection Procedure}

To assess the effectiveness of consciousness-raising activities through listening prompts on the learners' perceptions of the speech act of apology, MDCT was employed as both pre-test and post-test. First, to reassure that all the participants were homogenized in terms of their L2 proficiency, "Nelson English Language Proficiency Test" was administered prior to the treatment and as it was expected, all the learners' scores enjoyed the homogeneity criterion. Then they were randomly and equally assigned to two groups of experimental and control.

The treatment, which was based on both explicit and implicit instruction of apology speech act through the receptive skill of listening, commenced immediately after the pre-test was conducted and lasted 14 sessions throughout a semester. The experimental group was exposed to listening prompts and consciousness-raising activities, while the control class received the mere instruction with no attempt to raise their awareness of the pragmatic features of the prompts. Learners in both groups were presented one or two apology listening prompt(s) each session and after a couple of sessions; the previously taught LPs were reviewed.

While the non-experimental group was instructed the speech act of apology solely by listening to authentic conversations and doing some vocabulary exercises(on their transcribed conversation text) at the expense of consciousness-raising pragmatic tasks, the C-R class was provided with various types of pragmatic-oriented activities such as: providing appropriate equivalent alternatives for the phrases or sentences within each apology situation they heard; specifying the social status of the interlocutors in the structured forms; determining different types of apologizing strategies; and role play activities of the intended apology speech act situation. Such tasks which involved sociopragmatic as well as pragmalinguistic features set the scene for subsequent teacher-fronted discussions and explicit comments on the apology speech act LP as a feedback phase to the whole class. Ultimately, at the end of the treatment period, the same MDCT was adopted to conduct the post-test with both groups of learners.

\subsection{Data Analysis}

In order to examine the effectiveness of consciousness raising listening prompts on the perception of the speech act of apology, first of all, descriptive statistics including means and standard deviations were computed to summarize the students' responses to the pretest and the posttest. In order to explore the first two research questions, an independentsamples $t$-test was conducted to compare the means of the two groups' gain scores. The alpha level was set at 0.05 .

On the other hand, to find out whether the contextual factor of gender affects Iranian EFL learners' pragmatic comprehension with regard to receptive skill-based teaching of the speech act of apology(the third research question), descriptive statistics were computed. Then, to see whether the mean difference between males and females is significant or not, a paired-sample t-test was run. It must be noted that all the statistical analyses were conducted by using the Statistical Package for Social Sciences (SPSS 19.0) program. Finally, the results were interpreted and discussed and their implications were pointed out.

\section{Results}

\subsection{Results Related to the First and Second Research Questions}

To answer the first two research questions concerning the effect of explicit instruction of apology speech act through listening receptive skill on Iranian EFL learners' pragmatic competence on the one hand, and the role of consciousnessraising (C-R) tasks in their ILP development on the other hand, an independent samples $t$-test was run to compare the means of pre-test and post-test scores between $\mathrm{C}-\mathrm{R}$ and non-C-R groups. Table 1 indicates the descriptive statistics and the results of $t$-test. 
Table1. Descriptive statistics and the results of t-test regarding the perception of speech act of apology

\begin{tabular}{lll}
\hline Group & $\begin{array}{l}\text { Speech Act Perception in } \\
\text { pre-test post-test }\end{array}$ \\
\hline & Mean \pm SD & Mean \pm SD \\
Control & $11.81 \pm 3.24$ & $12.09 \pm 3.36$ \\
Experimental & $11.75 \pm 2.98$ & $15.22 \pm 3.79$ \\
Total & $11.78 \pm 3.09$ & $13.66 \pm 3.87$ \\
p-value & .936 & .001 \\
\hline
\end{tabular}

As the results of the statistical analysis depict, unlike the students' performance on the pre-test which led to no significant difference between the two groups, the post-test marked a noticeable discrepancy between the non C-R and $\mathrm{C}-\mathrm{R}$ groups; that is, the experimental group outperformed their control counterpart in their recognition and comprehension of the speech act of apology. It is, hence, deduced that listening-based instruction of communicative act of apology through authentic materials, especially when accompanied by consciousness-raising activities has a beneficial effect on EFL learners' pragmatic competence.

\subsection{Results Related to the Third Research Question}

To explore the impact of gender on learners' speech act perceptions, a paired-sample t-test (Table 2) was run to make certain if there is any significant difference between the mean scores of the males and females in both the non-C-Rand C-R groups.

Table 2. Descriptive statistics and the results of paired-sample t-test for the perception of apology between male and female participants of two groups in pre-test

\begin{tabular}{llccc}
\hline Group & Sex & $\mathrm{N}$ & Mean \pm SD & p-value \\
\hline Control & Female & 15 & $12.27 \pm 3.97$ & 0.479 \\
& Male & 17 & $11.41 \pm 2.43$ & \\
Experimental & Female & 15 & $12.37 \pm 3.13$ & 0.045 \\
& Male & 17 & $10.76 \pm 2.49$ & \\
\hline
\end{tabular}

According to Table 2,performance of both male and female learners of the control group in pre-test revealed almost similar perceptions about the speech act of apology $(\mathrm{p}=0.479)$.On the other hand, performance of the experimental group marked a significant difference between the females and males regarding their pragmatic perception $\left(\mathrm{p}=0.045,{ }^{*} \mathrm{p} \leq 0.05\right)$.

To compare the performance of the two groups in post-test and to scrutinize any trace of gender effect on the learners' perceptions of apology act, another paired-sample t-test, the results of which are presented in the following Table, was conducted.

Table 3. Descriptive statistics and the results of paired-sample t-test for the perception of apology between male and female participants of two groups in the post-test

\begin{tabular}{|c|c|c|c|c|}
\hline Group & Sex & $\mathrm{N}$ & Mean \pm SD & $p$-value \\
\hline Control & Female & 15 & $12.73 \pm 4.044$ & 0.335 \\
\hline Male & 17 & $11.53 \pm 2.63$ & & \\
\hline Experimental & Female & 15 & $16.93 \pm 3.17$ & 0.012 \\
\hline Male & & 17 & $13.71 \pm 3.64$ & \\
\hline
\end{tabular}

Again, with regard to the learners' speech act perception, the post-test led to no significant difference between females and males of the control group $(\mathrm{p}=0.335)$.However, in the experimental group, gender came out to exert a significant impact on the way females and males perceived the communicative act of apology $\left(\mathrm{p}=0.012,{ }^{*} \mathrm{p} \leq 0.05\right)$; Accordingly, it is inferred from the results that the female learners of the experimental group had a better performance in both pre- and post-tests than their male counterparts. To put it in a nutshell, the contextual factor of gender did not tangibly affect the control group's pragmatic awareness, whereas in the experimental group, gender effect was of paramount importance, particularly to female learners' recognition of apology speech act. 


\section{Discussion and Conclusion}

The present study evaluated the relative effectiveness of listening-based pragmatic instruction with regard to the comprehension of the illocutionary act of apology.As its central themes, this study scrutinized the influential impact of explicit instruction and consciousness-raising tasks on EFL learners' pragmatic awareness on the one hand, and the role of gender on the way the learners perceived the act of apology through the receptive mode of listening prompts, on the other hand. Regarding the first two research questions, the results not only confirmed the pivotal role of instruction in boosting EFL learners' interlanguage pragmatic perceptions, but also verified the consequential impact of awarenessraising activities on their ILP competence.

The findings of the first research inquiry are compatible with those of Gholamia and Aghaeib's (2012) enquiry, Kargar et al.'s (2012) as well as Birjandi and Derakhshan's (2014) investigations which advocated the effectiveness of various instructional paradigms on the perception and production of communicative acts within Iranian EFL contexts. The obtained results of the current study are in line with the findings of other types of empirical attempts, as well. In addition to Eslami-Rasekh and Mardani (2010) who showed the usefulness of explicit teaching of the illocutionary act of apology, Eslami-Rasekh et al. (2004) also verified the effect of explicit metapragmatic instruction on the speech acts comprehension of requesting, apologizing, and complaining among advanced EFL students.

As far as the second research question was explored, the statistical analyses revealed that the participants in the C-R group outperformed the non-C-R group on the post-test. In other words, there was a significant difference in the performance of learners taught through raising consciousness of listening prompts and that of students taught by a traditional method. These findings, concerning the effects of consciousness raising activities in ILP field, are consistent with the results of some previous inquiries, namely Barekat and Mehri's (2013) recent work on the role of consciousness-raising pragmatic instruction. Besides, Takimoto (2006)has provided empirical evidence for the claim that pragmatic features can be taught explicitly or implicitly together with input enhancement activities. He evaluated the relative effectiveness of two types of input-based instruction, consciousness-raising instruction and consciousnessraising instruction with feedback for teaching English polite requestive forms. The results of data analysis indicated that the two C-R groups outperformed the non-C-R group.

The last research concern, which addressed the differences between the male and the female learners in the way they perceived the speech act of apology, yielded no gender effect on the control group's pragmatic comprehension, where as within the experimental group, this contextual factor gave rise to significant discrepancy, with female learners' better performance on apology MDCT. This finding is in line with what Farashaiyan and Tan (2012) found as a result of their probe into the relationship between gender, language proficiency, and pragmatic knowledge. It came out that female learners performed more satisfactorily on the tests than their male partners did. The ultimate result of the present study is also congruous with the findings of Safa and Mahmoodi's (2012) inquiry that exhibited not only a positive interaction between EFL learners' lexico-grammatical and pragmatic competences, but also a stronger mutual association between female learners' competencies.

\section{Pedagogical Implications}

Regarding pedagogical implications, it is hoped that the findings of this research would be beneficial not only to curriculum designers and material developers, but also to textbook writers as well as language teachers. Raising awareness of the pragmatic aspects of language may help curriculum designers to develop more pragmatic-oriented curricula and material developers to incorporate authentic, communicative, and skills-based tasks into L2 teaching/learning programs. The paucity of explicit instruction of IL pragmatic features and of L2 functions or illocutionary acts in many language textbooks (Eslami-Rasekh \&Mardani, 2010), on the other hand, may and should urge textbook writers to expand the pragmatic scope of the books toward a more functional approach, so that the inclusion of various universal speech acts within the content of such books necessitate their direct instruction on the part of teachers. Considering the constructive role of consciousness-raising tasks in enhancing EFL learners' pragmatic competence, language teachers are to revisit their teaching methods to integrate as more authentic and interactive tasks as required according to their learners' target needs. Furthermore, language teachers are supposed to recognize and appreciate the learners' individual differences in order to regulate their teaching according to students' linguistic, sociolinguistic, and especially pragmatic competence.

The present study implies several directions for enthusiastic investigators to increase the depth and breadth of probe within the realm of L2 pragmatics. Accordingly, follow up research may include cross-cultural apology speech act scrutiny to investigate the effect of not only explicit instruction, but also implicit instructional techniques on interlanguage pragmatic comprehension. Another line of inquiry would be comparative studies of the role of classroom teaching on pragmatic perception of EFL learners of various proficiency levels. It seems also insightful to trace the instructional role of various types of authentic materials supplied by either of the two receptive modes (i.e. reading or listening) in sensitizing L2 learners towards pragmalinguistic as well as sociopragmatic features of the very communicative activities they are engaged in.

\section{Acknowledgements}

The researchers wish to express their sincere gratitude to those students who participated in this study, and they would also like to specially thank the Editor-in-Chief and the anonymous reviewers for their valuable and helpful comments and suggestions. 


\section{References}

Achiba, M. (2003). Learning to request in a second language: A study of child interlanguage pragmatics. Clevedon, England: Multilingual Matters, Second Language Acquisition Series.

Afghari, A., \&Karimnia, A. (2007).A contrastive study of four cultural differences in everyday conversation between English and Persian. Intercultural Communication Studies, 16(1), 243.

Afghari, A., \&Karimnia, A. (2012).On apologizing in Persian: A socio-cultural inquiry. Jezikoslovlje, 13(3), 697-734.

Alcón, E. (2005). Does instruction work for learning pragmatics in the EFL context? System, 33(1), 417-435.

Alcón, E., \&Pitarch, J. G. (2010). The effect of instruction on learners' pragmatic awareness: A focus on refusals. International Journal of English Studies. 10(1), 65-80.

Austin, J. L. (1962). How to do things with words? Oxford: Oxford University Press.

Bachman, L. \& Palmer, A. (1996).Language testing in practice. Oxford: Oxford University Press.

Bardovi-Harlig, K. (2001). Evaluating the empirical evidence. Grounds for instruction in pragmatics? In K. R. Rose \& G. Kasper (Eds.), Pragmatics in language teaching (pp. 13-32). Cambridge: Cambridge University Press.

Bardovi-Harlig, K., \& Hartford, B. S. (1993).Learning the rules of academic talk. Studies in Second Language Acquisition, 15(03), 279-304.

Barekat, B., \& Mehri, M. (2013).Investigating the effect of metalinguistic feedback in L2 pragmatic instruction. International Journal of Linguistics, 5(2), 197-208.

Bergman, M. L., \& Kasper, G. (1993).Perception and performance in native and nonnative apology. Interlanguage Pragmatics, 4(1),82-107.

Birjandi, P., \&Derakhshan, A. (2014).The impact of consciousness-raising video-driven vignettes on the pragmatic development of apology, request, \& refusal. Applied Research on English Language, 3(1), 67-85.

Blum-Kulka, S., House, J., \& Kasper, G. (1989).Cross-cultural pragmatics: Requests and apologies. Norwood, NJ: Ablex.

Blum-Kulka, S., \&Olshtain, E. (1984). Requests and apologies: A cross-culture study of speech act realization patterns (CCSARP). Applied Linguistics, 5(3), 196-213.

Canale, M., \& Swain, M. (1980). Theoretical aspects of communicative approaches to second language teaching and testing. Applied Linguistics, 1(1), 1-47.

Celce-Murcia, M. (2001).Teaching English as a second or foreign language. Heinle \&Heinle Publishers.

Cohen, A. D. (1996). Developing the ability to perform speech acts. Studies in Second Language Acquisition, 18(3), 253-267.

DeVellis, R.F. (1991). Scale development. Newbury Park, NJ: Sage Publications.

Doughty, C. J. (2003).Instructed SLA: Constraints, compensation and enhancement. InC. J. Doughty and M. H. Long (Eds.),Handbook of second language acquisition (pp. 256-310). Malden, MA: Blackwell.

Ellis, R. ( 2003). Task-based language learning and teaching. Oxford: Oxford University Press.

Eslami-Rasekh, A. \&Mardani, M. (2010).Investigating the effects of teaching apology speech act, with a focus on intensifying strategies on pragmatic development of EFL learners: The Iranian context. The International Journal of Language Society and Culture,30(1), 96-103.

Eslami-Rasekh, Z. (2004). Face keeping strategies in reaction to complaints: English and Persian. Journal of Asian Pacific Communication, 14(1), 181-198.

Eslami-Rasekh, Z. (2005). Raising the pragmatic awareness of language learners.ELT Journal, 59(3), $199-208$.

Eslami-Rasekh, Z., Eslami-Rasekh, A., \&Fatahi, A. (2004). The effect of explicit metapragmatic instruction on the speech act awareness of advanced EFL students. TESL-EJ, 8(2), 1-12.

Farashaiyan, A., \& Tan, K. H. (2012).On the relationship between pragmatic knowledge and language proficiency among Iranian male and female undergraduate EFL learners.3L; Language, Linguistics and Literature, The Southeast Asian Journal of English Language Studies, 18(1), 33-46.

Fowler, W. S.,\& Coe, N. (1976).Nelson English language tests. Victoria: Thomas Nelson Ltd.

Garcia, C. (1989). Apologizing in English: Politeness strategies used by native and non-native speakers. MultilinguaJournal of Cross-Cultural and Interlanguage Communication, 8(1), 3-20.

Gass, S. M., \&Selinker, L. (2008).Second language acquisition: An introductory course. Taylor \& Francis.

Gholamia, J., \& Aghaeib, H. K. (2012). The impact of explicit and implicit instruction on Iranian EFL learners' production and recognition of language functions. International Journal of Physical and Social Sciences,9 (2), $107-$ 131.

Grice, P. (1975). Logic and conversation. In P. Cole \& J. Morgan (Eds.), Speech acts (pp. 41-58). New York: Academy Press. 
Holmes, J. (1989). Sex differences and apologies: One aspect of communicative competence. Applied Linguistics, 10(2), 194-213.

House, J. (1988). Oh excuse me please...”: Apologizing in a foreign language. EnglischalsZweitsprache, 30(3),13-27.

Hymes, D. H. (1972).On communicative competence.In B. Pride\&Y. J. Holmes (Eds.),Sociolinguistics (pp. 46-59). Harmondsworth: Penguin.

Judd, E. L. (1999). Some issues in the teaching of pragmatic competence. Culture in second language teaching and learning, 5(3), 152-166.

Kargar, A., Sedighi, F., \&Ahmadi, A. R. (2012).The effects of collaborative translation task on the apology speech act production of Iranian EFL learners. The Journal of Teaching Language Skills (JTLS),4(3), 47-78.

Kasper, G. (1992). Pragmatic transfer. Second Language Research, 8 (3), 203-231.

Kasper, G. (1997). Can pragmatic competence be taught? Network, 6(2), 105-119.

Kasper, G. (1998). Interlanguage pragmatics. In H. Byrnes (Ed.).Learning foreign and second languages: Perspectives in research and scholarship (pp. 183-208).New York: The Modern Language Association of America.

Kasper, G., \& Blum-Kulka, S. (Eds.) (1993).Interlanguage pragmatics. New York: Oxford University Press.

Kasper, G., \& Rose, K. R. (2002).Pragmatic development in a second language. Mahwah, NJ: Blackwell publishing.

Kasper, G., \& Schmidt, R. (1996). Developmental issues in interlanguage pragmatics. Studies in Second Language Acquisition, 18(1), 149-169.

Lakoff, R. T. (2001). Nine ways of looking at apologies: The Necessity for interdisciplinary theory and method in discourse analysis. The Handbook of Discourse Analysis, 18(2), 187-199.

Lightbown, P. M., Spada, N. (1999).How languages are learned. Oxford: Oxford University Press.

Littlewood, W. (1981).Communicative language teaching: An introduction. Cambridge: Cambridge University Press.

Martínez-Flor, A., \& AlcónSoler, E. (2007). Developing pragmatic awareness of suggestions in the EFL classroom: A focus on instructional effects. Canadian Journal of Applied Linguistics, 10(1), 46- 76.

Meier, A. (1996). Two cultures mirrored in repair work. Multilingua, 15,149-169.

Meier, A. (1997). Teaching the universals of politeness.ELT Journal, 51(1), 21-28.

Nunan, D. (1999). Second language teaching \&learning. Heinle \& Heinle Publishers.

Olshtain, E. \& Cohen, A. (1983). Apology: A speech act set. In Wolfson, N. and Judd, E. (Eds.), Sociolinguistics and language acquisition (pp.18-35). Rowley, MA: Newbury House.

Olshtain, E. \& Cohen, A. (1989): Speech act behavior across languages. In H.W. Dechert\& M. Raupach, (Eds.),Transfer in language production (pp. 53-67). Norwood: Ablex Publishing Corporation.

Omaggio Hadley, A. (1993). Teaching language in context. Boston: Heinle\&Heinle.

Qorina, D. (2012). "Realization of apology strategies by English department students of Pekalongan university. Language Circle,7(1), 36-49.

Richards, J. C. (2003). Developing tactics for listening: Student book. Oxford University Press.

Richards, J. C. (2005). Interchange I. Cambridge: Cambridge University Press.

Rintell, E. (1979). Getting your speech act together: The pragmatic ability of second language learners. Working Papers on Bilingualism Toronto, 17, 97-106.

Rose, K. R. (2009). Interlanguage pragmatic development in Hong Kong, phase 2.Journal of Pragmatics, 41(2), 23452364.

Safa, M. A.,\& Mahmoodi, M. H. (2012). The interface between linguistic and pragmatic competence: The case of disagreement, scolding, requests, and complaints. Journal of English Language, 10 (3), 1-26.

Salazar, C. P. (2008). Examining mitigation in requests: A focus on transcripts in ELT course books. In Alcon Soler, E. \& SafontJordia, M. P. (Eds.),Intercultural language use and language learning (pp. 207- 222).Springer.

Saslow, J., \&Ascher, A. (2006).Top Notch Series. Pearson Education: New York.

Schmidt, R. (1993). Consciousness, leaning and interlanguage pragmatics. In G. Kasper \& S. Blum-Kulka (Eds.), Interlanguage pragmatics (pp.21-42).Oxford: Oxford University Press.

Schmidt, R. W. (1990). The role of consciousness in second language learning. Applied linguistics, 11(2), 129-158.

Searle, J.R. (1969). Speech acts: An essay in the philosophy of language. Cambridge: Cambridge University Press.

Soars, J., Soars, L., Falla, T., \& Cassette, W. (2002). American Headway: Starter: Student Book. Oxford University Press.

Stenstrom, A. B. (1994). An introduction to spoken interaction. London: Longman.

Taguchi, N. (Ed.) (2009). Pragmatic competence. New York, Berlin: MoutondeGruyter. 
Taguchi, N. (2010). Analysis of appropriateness in a speech act of request in L2 English. Pragmatics, 16(4), 56-69.

Takahashi, S. (2001).The role of input enhancement in developing pragmatic competence.In K.R. Rose \& G. Kasper (Eds.), Pragmatics in language teaching (pp.171-199). Cambridge: Cambridge University Press.

Takimoto, M. (2006).The effects of explicit feedback and form-meaning processing on the development of pragmatic proficiency in consciousness-raising tasks. System, 34(4), 601-614.

Takimoto, M. (2012).Metapragmatic discussion in interlanguage pragmatics. Journal of Pragmatics, 3, 1-14.

Tanck, S. (2002).Speech Act sets of refusal and complaint: A comparison of native and non-native English speakers production. Unpublished $\mathrm{PhD}$ dissertation.American University, Washington, DC.

Tehrani, M. D., Rezaei, O., Dezhara, S., \&Kafrani, R. S.(2012).Apology strategies of Iranian undergraduate students. English Language Teaching, 5(2), 93-109.

Thomas, J. (1983). Cross-cultural pragmatic failure. Linguistics, 4(2), 91-112.

Tuncel, R, (2011). Apologizing and speech act realizations of Turkish EFL learners. International Conference on Management, Economics and Social Sciences (ICMESS'2011) Bangkok Dec., 2011

Wierzbicka, A. (1985). Different cultures, different languages, different speech acts: Polish vs. English. Journal of Pragmatics, 9(2), 145-178.

Wong, S. M. L. (1994). Imperatives in requests: Direct or impolite-observations from Chinese. Pragmatics, 4(2), 491515 .

Yoshimi, D. R. (2001). Explicit instruction and JFL learner's use of interactional discourse markers. In K.R. Rose \& G. Kasper (Eds.), Pragmatics in language teaching (pp. 223-244).Cambridge:Cambridge University Press.

Zimin, S. (1981). Sex and politeness: Factors in first- and second-language use. International Journal of the Sociology of Language, 27, 35-58. 